\title{
MODEL PEMBERDAYAAN KELEMBAGAAN USAHA MIKRO \& KECIL (UMK) PADA UNIT TELKOM CDC PT. TELEKOMUNIKASI INDONESIA, Tbk.
}

\author{
Ida Nurnida Relawan \\ Program Studi S1 Ilmu Administrasi Bisnis - Fakultas Komunikasi \& Bisnis - Telkom University \\ E-mail: nurnida@telkomuniversity.ac.id
}

\begin{abstract}
ABSTRAK. Pemberdayaan Usaha Mikro dan Kecil (UMK) memiliki posisi penting dalam perekonomian Indonesia, antara lain ditunjukkan dengan kontribusinya terhadap jumlah unit usaha $(99,91 \%)$ dan penyerapan tenaga kerja (94,31\%). Luasnya wilayah Indonesia, menjadi salah satu tantangan tersendiri bagi pemerintah dalam upaya pemberdayaan UMK, karena itu, selain pembentukan Kementerian Koperasi \& UKM, pemerintah juga melibatkan partisipasi aktif Badan Usaha Milik Negara (BUMN) melalui pelaksanaan Program Kemitraan yang diatur dalam PER-05/MBU/2007. PT.Telkom adalah salah satu BUMN yang menunjukkan keberhasilan dalam pelaksanaan Program Kemitraan. Tujuan penelitian ini adalah merekonstruksikan pemodelan atas pelaksanaan Program Kemitraan yang dilakukan oleh PT. Telkom, dengan menggunakan metode kualitatif. Hasil penelitian menunjukkan bahwa PT. Telkom menjabarkan PER-05/MBU/2007 ke dalam KD.21/2010, dan membentuk unit Telkom CDC untuk pelaksanaannya. Kesimpulan penelitian adalah bahwa pelaksanaan Program Kemitraan oleh Telkom CDC sukses dengan kinerja $>100 \%$, karena didukung adanya komitmen manajemen perusahaan dalam merealisasikan Program Kemitraan secara komprehensif dan konsisten, yang dilakukan melalui tata kelola yang baik (good governance). Namun sebaiknya perusahaan melakukan penyesuaian KD.21/2010 yang mengatur tugas pokok dua hierarkhi, yaitu Telkom CDC (Pusat/kebijakan) dan Telkom CDA (Wilayah/ evaluasi), karena realisasi di lapangan menunjukkan tiga hierarkhi yang memegang peran penting dalam menjalankan tugas pokok Program Kemitraan, yaitu Telkom CDC, Telkom CDA, dan Telkom CDSA (Daerah/pelaksanaan proses teknis).
\end{abstract}

Kata kunci: Model, Pemberdayaan, Kelembagaan, Usaha Mikro \& Kecil (UMK), Perekonomian

\section{EMPOWERMENT MODEL INSTITUTION MICRO \& SMALL ENTERPRISES (MSEs) THE UNIT PT TELKOM CDC. Telekomunikasi Indonesia, Tbk.}

ABSTRACT. Empowerment of Micro and Small Enterprises ( MSEs ) have an important position in the Indonesian economy, shown by its contribution to the number of business units (99.91\%) and labor absorption (94.31\%)

. The extent of the territory of Indonesia, become one of challenges for the government in efforts to empower SMEs, in order to, in addition to the establishment of the Ministry of Cooperatives and SMEs, the government also involves the active participation of the State Owned Enterprises (SOEs) through the implementation of the Partnership Program set forth by PER-05/MBU/2007. PT.Telkom is among SOEs which shows the successfully in the implementation of a Partnership Program. The purpose of this study is to reconstruct the model for the implementation of the Partnership Program conducted by PT. Telkom by using qualitative methods. The results showed that PT. Telkom describes PER-05/MBU/2007 into KD.21/2010, and forms the CDC Telkom unit for the implementation. Research conclusion is that the implementation of the Partnership Program by CDC Telkom success with the performance of $>100 \%$, because it supported by the Management commitment in the realization of a comprehensive and consistent program, which conducted by good governance. But should companies adjust governing KD.21/2010 which two basic tasks hierarchy, there are Telkom CDC (Center/policy) and Telkom CDA (Region/evaluation), because of the realization in the field shows three hierarchies that hold an important role in conducting the basic tasks of Partnership Programs, there are Telkom CDC, Telkom CDA, and Telkom CDSA (Local/conducting technical process).

Keywords: Models, Empowerment, Institutional, Micro and Small Enterprises (MSEs), Economy

\section{PENDAHULUAN}

Di banyak negara berkembang termasuk Indonesia, dinamika dan kinerja ekonomi yang baik dengan laju pertumbuhan tinggi adalah performa ekonomi nasional yang ditopang oleh kinerja usaha berskala mikro, kecil, dan menengah yang efisien, produktif, dan berdaya saing tinggi. ${ }^{1}$

Di Indonesia, penopang terpenting dan motor penggerak ekonomi nasional terutama adalah usaha berskala mikro dan kecil (UMK). Peran sentral UMK dalam perkembangan ekonomi bangsa, antara lain ditunjukkan dengan kontribusinya terhadap jumlah unit usaha $(99,91 \%)$ dan penyerapan tenaga kerja $(94,31 \%)$.

1 European Commision, 2012
UMK mulai dirasakan memiliki peran sentral dalam perekonomian nasional setelah krisis ekonomi terjadi tahun 1997, saat Indonesia berada di bawah pemerintahan orde baru. Saat itu orientasi pertumbuhan ekonomi disandarkan pada pengembangan usaha besar (konglomerasi), dengan harapan akan mendorong pertumbuhan UMK. Namun ternyata, krisis telah menghentikan keberhasilan pembangunan ekonomi Indonesia, yang berakibat banyaknya usaha konglomerasi yang mengalami kebangkrutan, sehingga terjadi pemutusan hubungan kerja (PHK) besar-besaran. Berbeda dengan usaha konglomerasi, UMK lebih cepat pulih dari krisis, dan tenaga kerja yang terkena PHK terserap ke dalam usaha berskala mikro dan kecil ini. Kecepatan pulih dan ketahanan 
UMK dalam menghadapi krisis ekonomi di Indonesia, banyak melahirkan UMK-UMK baru. Maka, mulailah orientasi pemberdayaan usaha berskala mikro dan kecil menjadi perhatian berbagai pihak. ${ }^{2}$

Luasnya wilayah Indonesia, terbatasnya kemampuan pemerintah, dan belum optimalnya pemberdayaan UMK di Indonesia, ${ }^{3}$ mendorong pemerintah melibatkan berbagai pihak. Di samping pembentukan Kementerian Koperasi \& UKM, pemerintah juga mengajak partisipasi aktif Badan Usaha Milik Negara (BUMN), melalui Peraturan Menteri Negara BUMN No. PER-05/MBU/2007.4 Salah satu BUMN penyelenggara Program Kemitraan UMK yang berhasil adalah PT. Telekomunikasi Indonesia, Tbk.

\section{Pemberdayaan}

Pemahaman pemberdayaan dapat dimulai dengan melakukan kajian tentang konsep "power". ${ }_{5}^{5}$ Power tergantung pada kemauan seseorang, ${ }^{6}$ dan memiliki banyak sumber, antara lain: kepribadian, property/ kekayaan, dan organisasi yang berpengaruh. ${ }^{7}$ Power (daya) didefinisikan sebagai kapasitas seseorang dan atau organisasi untuk menghasilkan sesuatu yang diinginkan, diperkirakan dan yang tidak terduga yang berpengaruh terhadap orang atau organisasi lainnya. ${ }^{8}$

Pemberdayaan adalah suatu proses, ${ }^{9}$ yang dilakukan seseorang, organisasi, dan atau suatu komunitas. ${ }^{10}$ Proses tersebut bersifat interaktif melalui "which people experience personal and social change, enabling them to take action to achieve influence over the organizations and institutions which affect their lives and the communities in which they live." 11 Tujuan dari proses interaktif tersebut adalah "gain mastery over issues of concern to them," "12 "individuals achieve increasing control of various aspects of their lives and participate in the community with dignity,"13 atau "enhancing an individual's or group's capacity to make choices and transform those choices into desired actions and outcomes." 14 Perspektif lain pemberdayaan adalah "the expansion of assets and capabilities of poor people to participate in, negociate with, influence, control, and hold accountable institutions that affect their live. ${ }^{15}$

4 Peraturan Menteri Negara BUMN No. PER-05/MBU/2007 Program Kemitraan Badan Usaha Milik Negara Dengan Usaha Kecil dan Program Bina Kemitraan Bad
Lingkungan.

5 Moscovitch and Drover, 1981 dalam Lord, John and Hutchison, Peggy. 1993: 2. The Process of Empowerment: Implications for Theory and Practic, Canadian Journal of Community Mental Health. 12:1, Spring 1993, pages 5-22.

6 Sadan, Elisheva .2004: 33. Empowerment and Community Planning. Tel. Aviv, Hakibbutz Hameuchad Publisher (in Hebrew).

Lord \& Hutchison, Peggy. 1993:2. The Process of Empowerment: Implications for Theon and Practic, Canadian Journal of Community Mental Health. 12:1, Spring 1993, pages 5-22. Cornell Empowerment Group, 1989: 2.

9 Perkins, Douglas D. And Zimmerman, Marc A. 1995: 570. Empowerment Theory, Research, and Application, American Journal of Community Psychology, Vol. 23, No.5. Plenum Publishing Corporation. USA

10 Rappaport, Julian. 1987 dalam Perkins, Douglas D. And Zimmerman, Marc A. 1995: 581. Empowerment Theory, Research, and Application, American Journal of Community Psychology, Vol. 23, No.5. Plenum Publishing Corporation. USA.

11 Withmore, E. 1988: 13. Participation, empowerment and welfare, Canadian Review of Social Policy, 22, 51-50

12 Rappaport, Julian 1987 dalam Zimmerman, Marc A. 1995: 581

13 Lord and Hutchison, Peggy,1993: 4.

14 Alsop, Ruth \& Nina Heinsohn 2005: 5. Measuring Empowerment in practice: Structuring Analysis and Framing indicators, World Bank Policy Research Working Paper $3510,1818 \mathrm{H}$. Street, NW. Washongton DC, 20433 USA.

15 Development Committee, World Bank, 2002: 11.
}

Bagi banyak peneliti, pemberdayaan juga dipandang sebagai fitur perubahan dalam peningkatan kekuatan kemapanan, emansipasi sosial, dan kebebasan manusia. ${ }^{16}$

Terdapat empat elemen penting dalam prinsipprinsip pemberdayaan, ${ }^{17}$ yaitu: 1) Poor people's assets and capabilities, bahwa masyarakat ekonomi lemah memerlukan berbagai aset (assets) dan kemampuan (capabilities) untuk meningkatkan kesejahteraan dan keamanan, serta kepercayaan diri mereka (self-confidence), sehingga mereka bisa bernegosiasi dengan pihak-pihak yang lebih kuat, 2) Relationship between Individual and Collective Assets and Capabilities, bahwa ada hubungan timbal balik antara aset dan kapabilitas individu dengan kemampuan untuk bertindak secara kolektif dalam suatu kelembaga-an, 3) Institutional Reform and Empowerment, bahwa dalam konteks kelembagaan, pemberdaya-an adalah tentang mengubah hubungan kelembagaan yang tidak setara, baik bersifat formal (meliputi hukum dan aturan yang melekat pada negara, sektor swasta, dan organisasi masyarakat sipil di tingkat lokal, nasional, maupun global), maupun bersifat informal (norma status inferior atau superior, hubungan kekerabatan, teman, dan tetangga), 3) No single model for empowerment, bahwa strategi pemberdayaan kelembagaan akan sangat bervariasi, tergantung pada konteks kelembagaan dan aspekaspek sosial, politik dan budaya di lingkungannya.

Pemberdayaan memiliki dimensidimensi, yang dapat dibagi ke dalam lima elemen utama, ${ }^{18}$, yaitu: 1) Access to Information, bahwa informasi adalah kekuatan (power). Masyarakat yang memiliki informasi yang lengkap akan lebih baik dan mudah dalam menangkap peluang, mengakses layanan, mendapatkan hak-hak mereka, dan akan mampu bernegosiasi secara efektif, 2) Inclusion, bahwa terdapat dua pihak kepesertaan (inclusion), yaitu pihak yang memberdayakan, apakah orang atau kelompok orang, organisasi, atau komunitas, dan pihak yang diberdayakan, yang dapat merupakan individu, kelompok, atau komunitas, 3) Participation, yaitu membahas pertanyaan: bagaimana mereka disertakan, dan apa peran mereka dalam kepesertaan tersebut?, 4) Accountability, mengacu pada kemampuan untuk menarik pejabat publik, pegawai swasta atau penyelenggara jasa untuk menjelaskan kebijakan, tindakan dan penggunaan dana mereka. Korupsi yang meluas, didefinisikan sebagai penyalahgunaan jabatan publik untuk keuntungan pribadi, yang akan sangat menyakiti masyarakat ekonomi lemah, karena mereka adalah yang paling tidak mungkin untuk memiliki akses langsung kepada pejabat dan paling tidak mampu untuk menggunakan koneksi untuk mendapatkan layanan. Mereka juga memiliki opsi paling sedikit untuk menggunakan layanan swasta sebagai alternatif, serta 5) Local organizational capacity, bahwa pada dasarnya, kehidupan komunitas

16 Campfens, 1997; Ife, 2002; Stein, 1997, dalam Whiteside, Mary Elizabeth. 2009:163. A Grounded Theory of Empowerment in the Context of Indigenous Australia, James Cook University, http://eprints.jcu.edu.au/8228

17 Development Committee - World Bank, 2002: 11-14 18 Ibid: $15-17$ 
masyarakat diselenggarakan dengan mengurus dirinya sendiri. Kapasitas organisasi lokal mengacu pada kemampuan orang-orang untuk bekerja bersama-sama, mengorganisasikan diri sendiri, dan memobilisasi sumber daya untuk memecahkan masalah yang menjadi kepentingan bersama.

Dimensi-dimensi yang terkandung dalam ke lima elemen utama pemberdayaan di atas, dapat dikombinasikan secara komprehensif untuk menciptakan pemberdayaan kelembagaan yang lebih efektif, responsif, inklusif dan akuntabel. ${ }^{19}$

\section{Kelembagaan \& Kelembagaan Usaha Mikro Kecil}

Secara konsepsional, kelembagaan adalah "the rules of the game in a society or, more formally, are the humanly devised constraints that shape human interaction."20 Kelembagaan berfungsi mengurangi ketidak pastian dan risiko yang disebabkan adanya keterbatasan rasionalitas manusia dan kemampuannya dalam mengakses informasi.21 Sedangkan mid,22 menjelaskan bahwa "Institutions are human relationships that structure opportunities via constraints and enab-lement. A constraint on one person is opportunity for another. Institutions enable individuals to do what they cannot do alone."

Dalam konteks kelembagaan Usaha Mikro dan Kecil (UMK), terdapat beberapa pengelompokkan, tergantung perspektif dalam pengelompokan tersebut. Peneliti menggunakan pengelompokan ke-lembagaan UMK berdasarkan UU. No. 20 tahun 2008, yaitu: 1) Usaha Mikro adalah usaha produktif milik perorangan dan atau badan usaha perorangan dengan kekayaan bersih paling banyak Rp.50 juta (lima puluh juta rupiah) tidak termasuk tanah dan bangunan tempat usaha atau memiliki hasil penjualan tahunan paling banyak Rp.300 juta (tiga ratus juta rupiah), dan 2) Usaha Kecil adalah usaha produktif yang berdiri sendiri yang dilakukan oleh perorangan atau badan usaha yang bukan merupakan anak perusahaan atau bukan cabang perusahaan yang dimiliki, dikuasai atau menjadi bagian, baik langsung maupun tidak langsung dari usaha menengah atau usaha besar. Yang memiliki kekayaan bersih lebih dari Rp.50 juta (lima puluh juta rupiah) tidak termasuk tanah dan bangunan tempat usaha, atau memiliki hasil penjualan tahunan lebih dari Rp.300 juta (tiga ratus juta rupiah) sampai dengan paling banyak Rp.2,5 milyar (Dua milyar rupiah).

\section{Pemodelan}

Sebagai dasar penyusunan pemodelan pemberdayaan dalam penelitian ini, peneliti menggunakan pemodelan yang bersifat konseptual, dengan cara mempelajari replika, model,

atau sesuatu yang menyerupai fenomena yang secara esensial paling menarik, namun lebih mudah dikelola, dan mudah untuk dipelajari. ${ }^{23}$

19 Development Committee, World Bank, 2002: 24

20 North, Douglas C. 1990: 3-4. Institutions, Institutional Change and Economic Performance. Cambridge: Cambridge University Press.

22 Schmid, Alan, A. 2004: 1. Conflict and Cooperation-Institutional and Behavioral Economics. ISBN 1-4051-1355-3; 1-4051-1356-1. Blackwell, Oxford, UK

23 Quade, 2010: 138-139. Analysis for Public Decisions, Third Editions, Revised Edition by Grace M., Carter, A Rand Corporation Research Study, North-Holland, Amesterdam.
Menurut Quade, semua model memiliki aspek tertentu yang sama, yaitu idealisasi, abstraksi dari beberapa bagian dari dunia nyata, dan masing-masing merupakan representasi lengkap dari hal yang nyata, atau dengan kata lain model adalah suatu tiruan dari realitas. ${ }^{24}$

Proposisi penelitian adalah model pemberdayaan kelembagaan Usaha Mikro Kecil (UMK) pada unit Telkom CDC, PT. Telekomunikasi Indonesia, Tbk.

\section{Pengukuran Pemberdayaan}

Pengukuran pemberdayaan dirumuskan melalui kerangka kerja analisis struktur dan perumusan indikatornya, mulai dengan penjabaran kapasitas (capacity) yang digunakan. ${ }^{25}$ Kapasitas dalam definisi ini dipengaruhi oleh dua faktor utama yang saling berhubungan, yaitu: badan (agency) dan struktur kesempatan (opportunity structure). Badan (agency) didefinisikan sebagai kemampuan seseorang atau suatu kelompok untuk menentukan pilihan yang berarti (the capacity to make meaningful choice). Badan (agency) tidak identik dengan pemberdayaan, artinya, ketika seseorang atau kelompok memiliki kapasitas untuk memilih, mereka mungkin tidak dapat menggunakan badan yang efektif, karena dibatasi oleh struktur peluang (opportunity structure). Struktur peluang sendiri didefinisikan sebagai aspek-aspek dalam konteks kelembagaan di mana para pelaku melakukan kegiatan yang dipengaruhi oleh kemampuan mereka yang akan mengubah badan (agency) ke dalam tindakan, sebagaimana digambarkan pada Gambar 1.

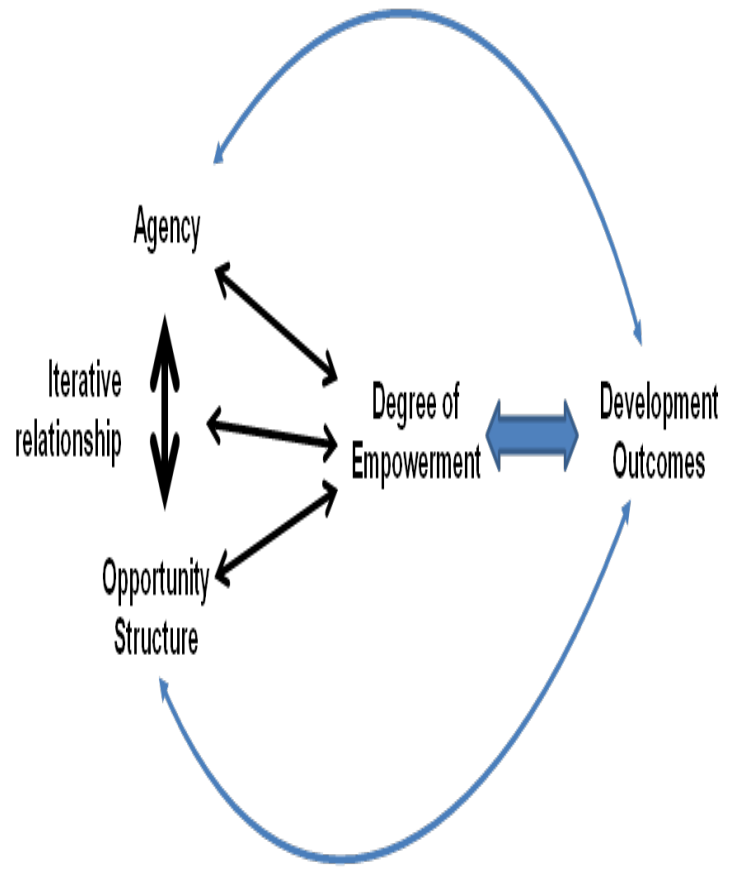

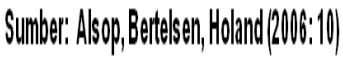

Gambar 1 Hubungan antara Manfaat dan Korelasi Pemberdayaan 24 Ibid.

25 Alsop, Bertelsen, and Holland, 2006: 9-21 Empowerment in practice : from analysis to implementation, HN49.C6A375-2006, The International Bank for Reconstruction and Development/THE WORLD BANK, 1818 H Street, NW, Washington, DC 20433 USA. 


\section{METODE}

Metode dalam penelitian ini adalah kualitatif dengan pendekatan induktif. Strategi yang digunakan adalah studi kasus, yaitu menyelidiki secara cermat terhadap peristiwa, kegiatan, dan proses, dari individu, kelompok, dan atau komunitas yang terlibat di dalam suatu proses ${ }^{26}$ yaitu pemberdayaan kelembagaan UMK yang dilakukan Telkom Community Development Centre (Telkom CDC) ${ }^{27}$. Teknik pengumplan data dilakukan melalui observasi, dokumentasi, dan wawancara terhadap informan yang terlibat langsung dalam proses pemberdayaan kelembagaan UMK ini, yaitu pihak pemberdaya dari unit Telkom CDC yang meliputi Senior General Manager (SGM) sebagai pimpinan puncak, Senior Manager (SM) Program Kemitraan, para Manager terkait Telkom CDC, Manager Telkom Community Development Area (Telkom CDA) Wilayah Jawa Barat dan Banten, serta Oficer Telkom Community Development Sub Area (Telkom CDSA) Tasikmalaya, Garut, dan Bandung. Dari pihak yang diberdayakan peneliti menentukan 9 UMK Mitra Binaan Telkom CDC yang sukses, sebagai sampel purposif untuk pengukuran hasil pemberdayaan. Validasi data dilakukan melalui triangulasi sumber, dan analisis dilakukan secara deskriptif eksploratif, yaitu menggambarkan, mengungkapkan, dan menjelaskan proses yang diteliti secara menyeluruh (holistic).

\section{HASIL DAN PEMBAHASAN}

\section{Dasar Pelaksanaan dan Pengelolaan (Governance) Program Kemitraan pada Telkom CDC}

Penyelenggaraan program pemberdayaan kelembagaan UMK melalui Program Kemitraan UMK Mitra Binaan oleh Telkom CDC dilakukan dengan tujuan meningkatkan kemampuan usaha kecil agar menjadi tangguh dan mandiri melalui pemanfaatan dana dari bagian laba Telkom.28 Dalam upaya pencapaian tujuan Program Kemitraan, perusahaan telah menetapkan empat prinsip,29 yaitu:1) Accountability, pencapaian sasaran baik kejelasan fungsi, pelaksanaan dan pertanggungjawaban di dalam pengelolaan dana maupun manfaat dari program yang diselenggarakan sehingga pengelolaannya efektif dan efisien, 2) Independency, pengelolaan dana program kemitraan yang dilakukan secara professional tanpa benturan kepentingan dan pengaruh serta tekanan dari pihak manapun yang tidak sesuai dengan ketentuan yang berlaku, 3) Fairness, memberikan perlakuan yang sama kepada masyarakat dan tidak mengarah untuk memberi keuntungan kepada pihak tertentu dengan cara dan alasan apapun, 4) Transparancy, semua proses pengambilan keputusan dalam mengemukakan ketentuan dan informasi, baik tata cara, evaluasi dan

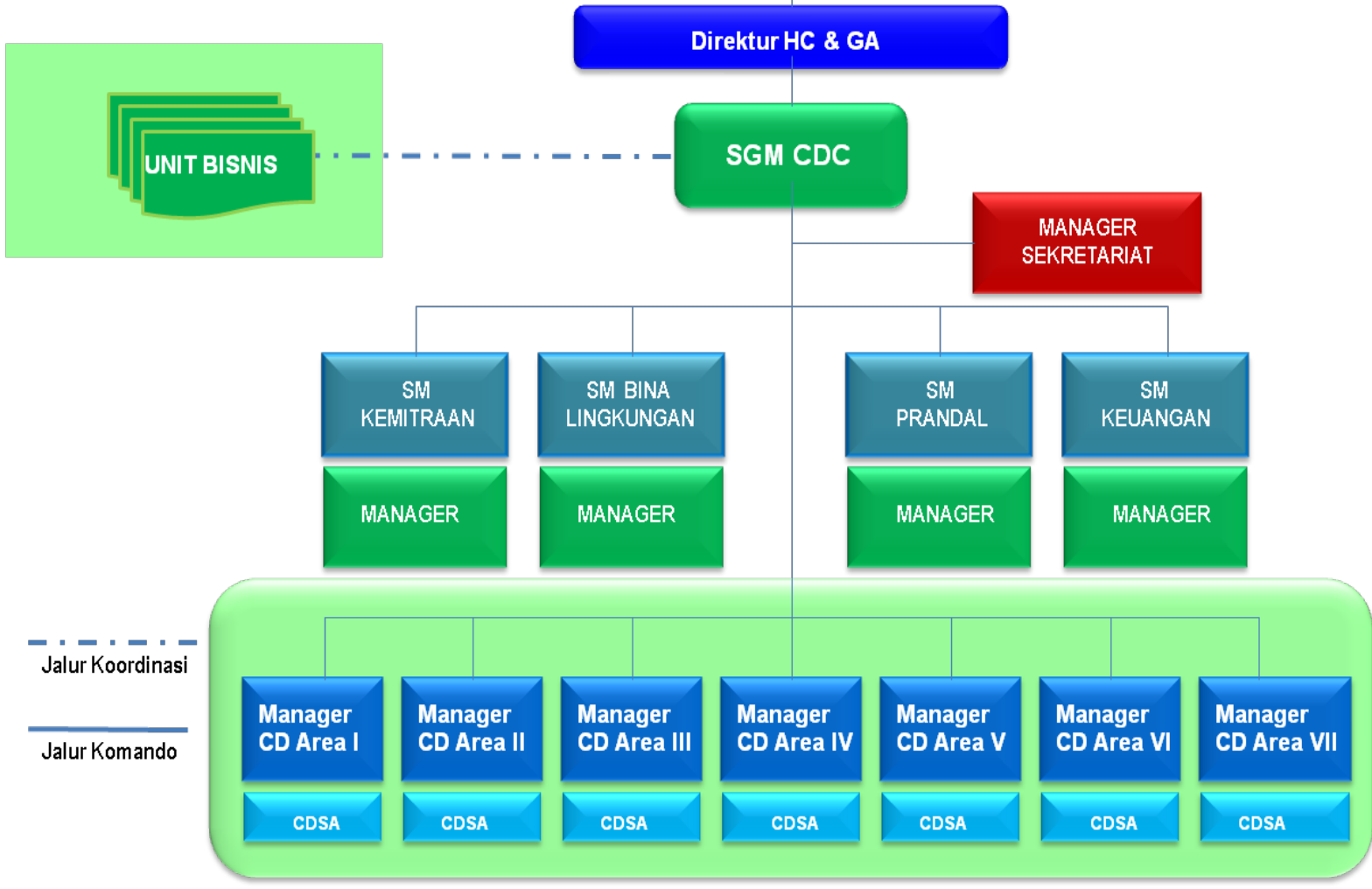

28 KD.21/PR000/COP-B0030000/2010 tanggal 19 April 2010 tentang Pengelolaan Program Kemitraan dan Program Bina Lingkungan. 29 Ibid 
5) Responsibility, Kesesuaian dalam tanggung jawab pengelolaan Program Kemitraan terhadap peraturan yang berlaku.

Kebijakan yang ditetapkan perusahaan untuk pengelolaan (governance) Program Kemitraan UMK Mitra Binaan Telkom CDC, hanya mengatur tugas dan wewenang pada dua level hierarkhi, ${ }^{30}$ yaitu Telkom CDC pada tingkat Pusat, dan Telkom CDA pada tingkat Wilayah. Berdasarkan hasil penelitian di kantor pusat Telkom, Jl. Japati No. 1 lantai 6, Bandung $^{31}$ terungkap bahwa proses pemberdayaan kelembagaan UMK Mitra Binaan Telkom CDC meliputi tiga level hierarkhi, yang menurut pendapat peneliti semua level memegang peran penting bagi keberhasilan pelaksanaan program. Pengelolaan Program Kemitraan UMK Mitra Binaan Telkom CDC secara komprehensif, adalah: 1) Telkom CDC pada tingkat Pusat/ Corporate, sebagai pengambil kebijakan, penyusun prosedur, menetapkan Rencana Kegiatan dan Anggaran (RKA) Program Kemitraan, memberkan persetujuan (approval) atas usulanusulan Telkom CDA/Witel, dan melakukan transfer dana bantuan pinjaman langsung kepada calon Mitra Binaan yang disetujui, 2) Telkom CDA pada tingkat Area/ Witel, sebagai evaluator atas program-program yang diajukan oleh Sub Area/Kandatel dan mengusulkan calon Mitra Binaan yang lolos evaluasi, kepada Telkom CDC untuk ditetapkan dan mendapat approval, serta menginformasikan calon Mitra Binaan yang sudah mendapatkan approval kepada Telkom CDSA, dan 3) Telkom CDSA pada tingkat Sub Area/Kandatel, sebagai front liner yang membantu Telkom CDA untuk pelaksanaan tugas-tugas teknis dan rutin dalam proses pemberdayaan Mitra Binaan, di antaranya: menyebarkan informasi tentang adanya bantuan dana pinjaman, menerima proposal dari calon Mitra Binaan, melakukan survey kepada calon Mitra Binaan yang memberikan proposal, melakukan seleksi administratif dan kelayakan calon Mitra Binaan, serta mengusulkan calon Mitra Binaan yang lolos seleksi kepada Manajer CDA/Witel. Struktur organisasi unit Telkom CDC digambarkan pada Gambar 2.

\section{Proses Pemberdayaan Kelembagaan UMK Mitra Binaan oleh Telkom CDC}

Proses pemberdayaan kelembagaan UMK Mitra Binaan melalui Program Kemitraan Telkom CDC meliputi tiga kegiatan utama, ${ }^{32}$ yaitu: penyaluran dana pinjaman (Dropping), pengembalian dana pinjaman (Collecting), dan Pembinaan.

Berdasarkan penelitian, ketiga kegiatan tersebut secara rinci, adalah sebagai berikut: ${ }^{33}$ 1) Dropping 30 Ibid

31 Observasi lapangan dan wawancara dengan SGM Telkom CDC, SM Program Kemitraan, Manager Program Kemitraan, Manager Telkom CDA, dan Oficer CDSA Tasikmalaya, Garut, dan Bandung.

32 KD.21/PR000/COP-B0030000/2010 tanggal 19 April 2010 tentang Pengelolaan Program Kemitraan dan Program Bina Lingkungan.

33 Observasi lapangan dan wawancara dengan SGM Telkom CDC, SM Program Kemitraan, Manager Program Kemitraan, Manager Telkom CDA, dan Oficer CDSA atau salur. Penyaluran dana bantuan program kemitraan kepada calon Mitra Binaan, secara umum dilakukan Telkom CDC dalam ske-ma tiga periode pemberdayaan. Seluruh Mitra Binaan yang sudah terseleksi secara administratif dan kelayakan (berdasarkan survey) oleh Telkom CDSA, lolos evaluasi Telkom CDA) dan diusulkan Telkom CDA kepada Telkom CDC, dapat mengajukan maksimum tiga kali pinjaman dalam tiga periode. Setiap periode maksimum berjangka waktu dua tahun. Pinjaman ke dua dan ketiga dapat diajukan dan dipertimbangkan Telkom CDC apabila pinjaman sebelumnya sudah diselesaikan dengan baik (tidak bermasalah/ tidak

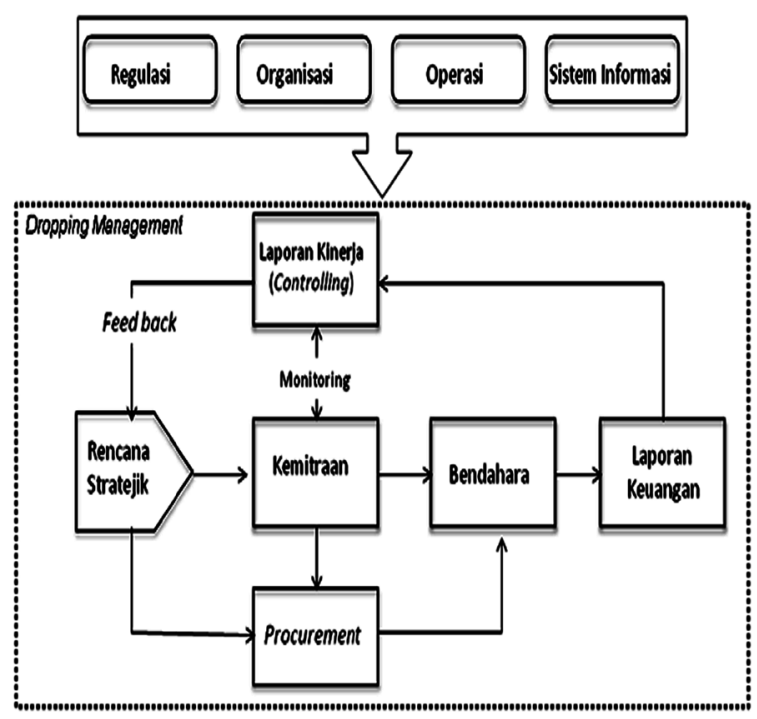

Sumber: Telkom CDC, diolah peneliti

Gambar 3 : Pengelolaan (Governance) Program Penyaluran Dana (Dropping) Pada Program Pemberdayaan Kelembagaan UMK Mitra Binaan Oleh Telkom CDC.

Untuk proses bisnis secara teknis, mekanisme dropping dibedakan berdasarkan statusnya, ${ }^{34}$ yaitu: Program Kemitraan Regular, Khusus, atau Sinergi BUMN berdasarkan MOU antara Kementerian BUMN dengan Telkom. Proses bisnis secara rinci

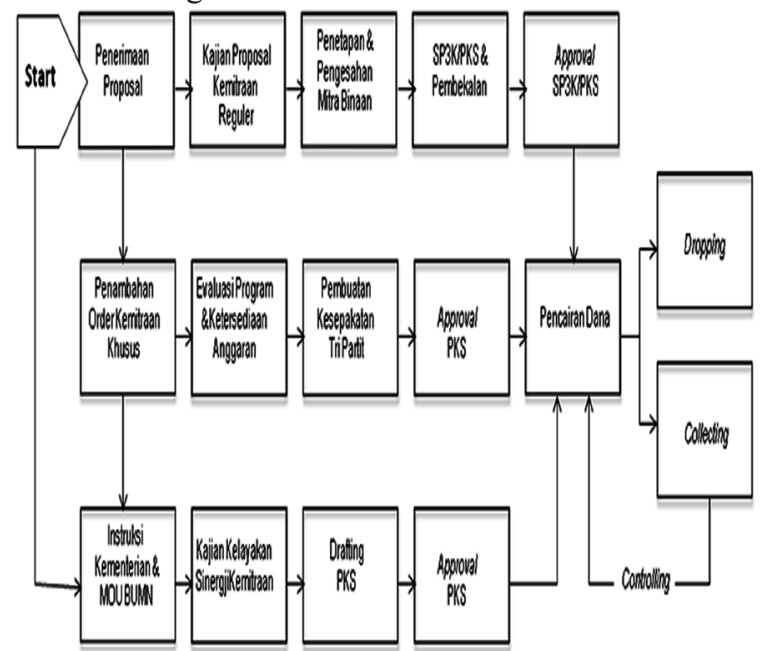

Sumber: Telkom CDC, diolah peneliti

Gambar 4: Mekanisme Penyaluran Dana Bantuan Pinjaman Program Kemitraan Telkom CDC Meliputi Kemitraan Reguler, Kemitraan Khusus, ndan Kemitraan Berdasarkan Instruksi Kementerian \& MOU BUMN.

Tasikmalaya, Garut, dan Bandung.

34 Observasi lapangan dan wawancara dengan SM Program Kemitraan. 


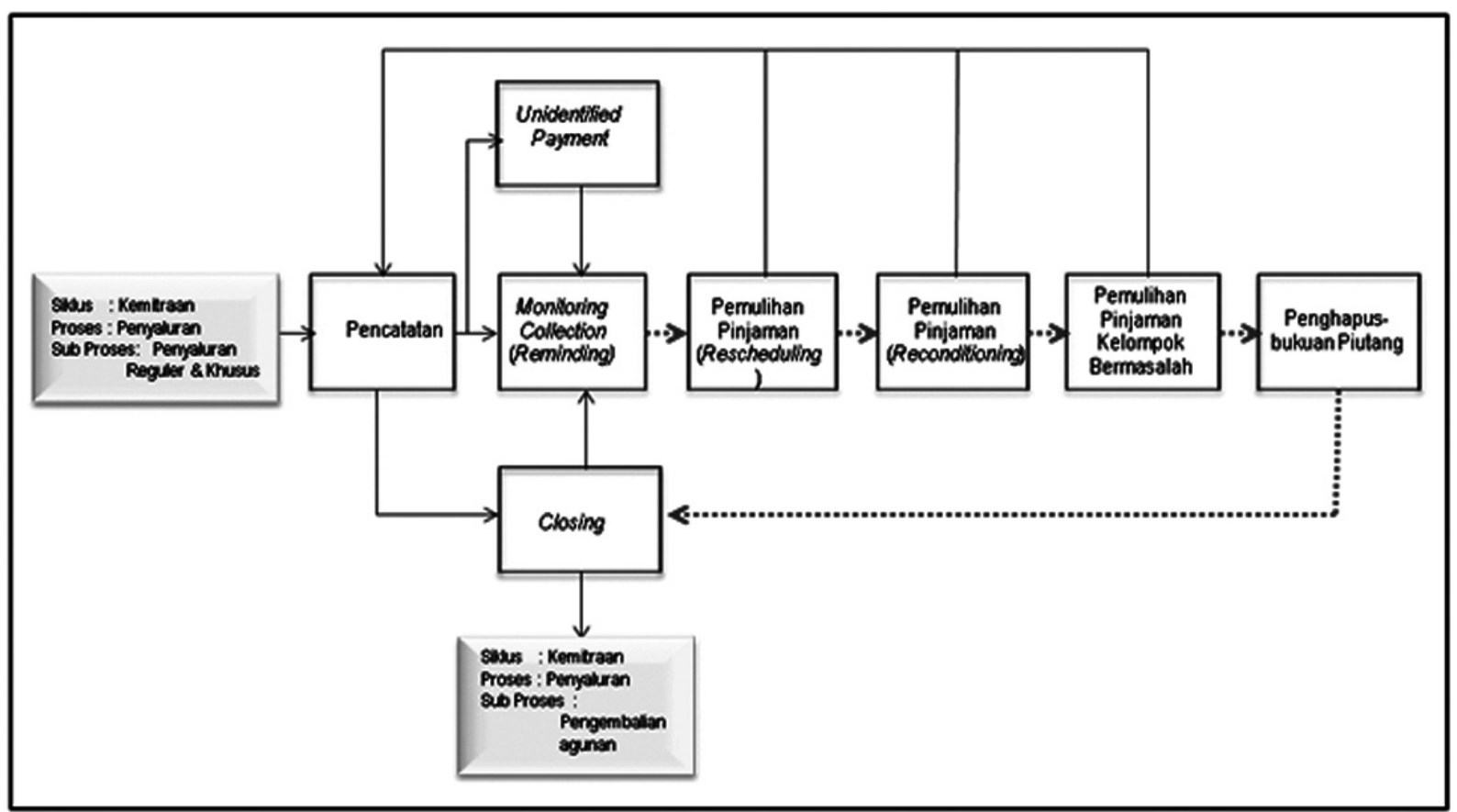

Sumber: Telkom CDC, diolah peneliti

Gambar 5 : Mekanisme Pengelolaan Collecting pada Program Kemitraan UMK Mitra Binaan Telkom CDC.

2) Collecting, yaitu pembayaran kembali pinjaman Program Kemitraan oleh Mitra Binaan yang dilaksanakan secara tepat waktu dan tepat jumlah sesuai perjanjian yang disepakati. Penerimaan angsuran pinjaman collecting, dilakukan oleh Telkom CDSA, yang berkedudukan di tingkat Kandatel. Angsuran piniaman terdiri dari nokok yang dibayarkan secara langsung oleh Mitra Binaan kepada Telkom CDC melalui rekening pada bank yang telah ditetapkan. Collecting terdiri dari beberapa kelompok, yaitu: regular, khusus, dan sinergi dengan BUMN lain. Proses bisnis collecting kelompokkelompok tersebut sebagaimana digambarkan pada

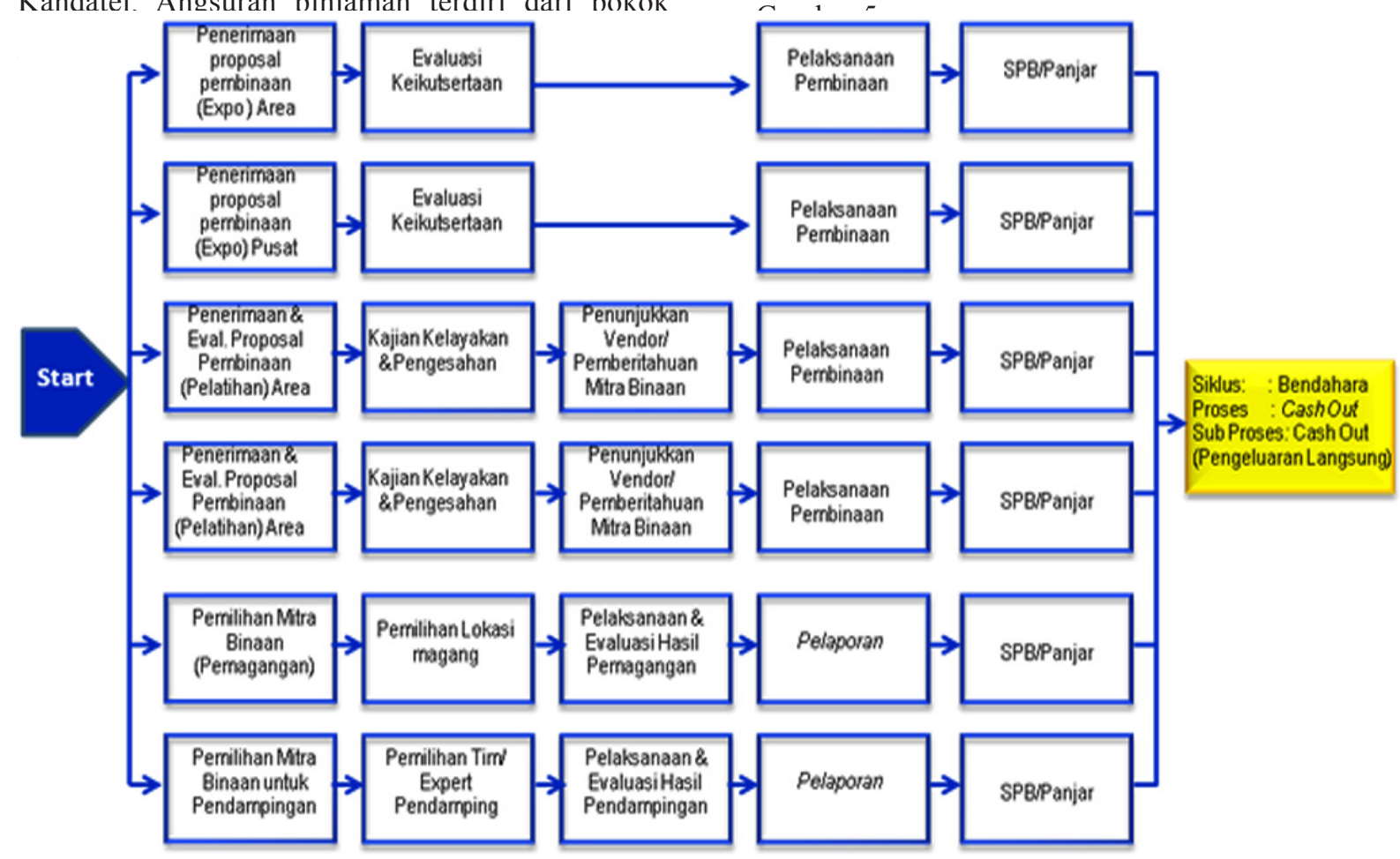

Sumber: Telkom CDC, diolah peneliti

Gambar 6 : Mekanisme Pengelolaan Program Pembinaan Melalui Kegiatan Pembekalan, Pendidikan \& pelatihan, Pemagangan, endampingan, Bantuan pemasaran \& promosi, dan atau Pameran/eksibisi. 
Collecting adalah kegiatan yang dirasakan paling berat oleh hierarkhi pelaksana teknis, yaitu Telkom CDSA yang langsung berhadapan dengan UMK Mitra Binaan. ${ }^{35}$ Untuk keberhasilan collecting, Telkom CDC melakukan strategi melalui penambahan proses bisnis terkait, ${ }^{36}$ yaitu: a) Proses bisnis monitoring collecting, baik melalui reminding call, reminding letter, maupun kunjungan petugas menjemput angsuran pembayaran dana bantuan pinjaman, ${ }^{37}$ baik untuk Program Kemitraan Reguler \& Khusus, maupun yang melalui sinergi dengan BUMN lain, b) Proses bisnis penyelesaian pembayaran tidak teridentifikasi, c) Proses bisnis untuk antisipasi kemungkinan pinjaman bermasalah dengan solusi rescheduling dan reconditioning, d) Proses bisnis pengembalian kelebihan bayar, e) proses bisnis penutupan (closing) pinjaman, f) Proses bisnis penghapusbukuan piutang, dan g) Proses bisnis pengelolaan agunan, dan kegiatan utama 3) Pembinaan. yaitu kegiatan yang diupayakan Telkom CDC untuk meningkatkan kemampuan UMK yang sudah menjadi Mitra Binaan menjadi suatu kelembagaan usaha yang tangguh dan mandiri. ${ }^{38}$ kegiatan utama Pembinaan pada Program Kemitraan Telkom CDC, meliputi: ${ }^{39}$ a) Pembekalan, yaitu pengarahan Telkom CDC kepada seluruh UMK Mitra Binaan yang akan mendapatkan dana bantuan pinjaman. Secara umum, pembekalan diselenggarakan pada saat mau dilakukan penandatanganan kontrak kerjasama pinjaman, b) Pendidikan \& pelatihan, yaitu kegiatan yang dilakukan berupa peningkatan nenoetahuan Ricnic Manaiemen dan Torhniral Skill c) Pemagangan, yaitu kegiatan yang dilakukan dengan cara Praktek Kerja atau Magang Usaha pada suatu institusi/lembaga profesional atau pada usaha perorangan professional tertentu, d) Pendampingan, yaitu mendatangkan ahli tertentu untuk melakukan bimbingan sesuai dengan kondisi dan kebutuhan UMK Mitra Binaan, e) Bantuan pemasaran \& promosi, yaitu kegiatan mempertemukan calon pembeli dengan UMK Mitra Binaan, dengan tujuan untuk memperagakan atau mempertunjukkan barang-barang hasil produksi UMK Mitra Binaan, dan f) Pameran/eksibisi, yaitu dengan cara mengikutsertakan UMK Mitra Binaan dalam pameran-pameran dengan tema yang rele-van dengan hasil produksi UMK Mitra Binaan, baik dalam negeri maupun luar negeri, dan lain-lain. Berikut adalah proses bisnis kegiatan-kegiatan tersebut. Mekanisme pembinaan, digambarkan pada Gambar 6 .

\section{Pemodelan Proses Pemberdayaan Kelembagaan UMK Mitra Binaan oleh Telkom CDC}

Berdasarkan hasil penelitian sebagaimana diurakan di atas, peneliti merncoba mengkons-truksikan proses pemberdayaan kelembagaan UMK Mitra Binaan oleh Telkom CDC dalam sebuah pemodelan, ${ }^{40}$ sebagai berikut: 1) Unsur-unsur atau elemen-elemen yang dipilih dalam pembangunan (construction) pemodelan adalah unsur-unsur yang relevan dengan pelaksanaan proses pemberdayaan kelembagaan UMK Mitra

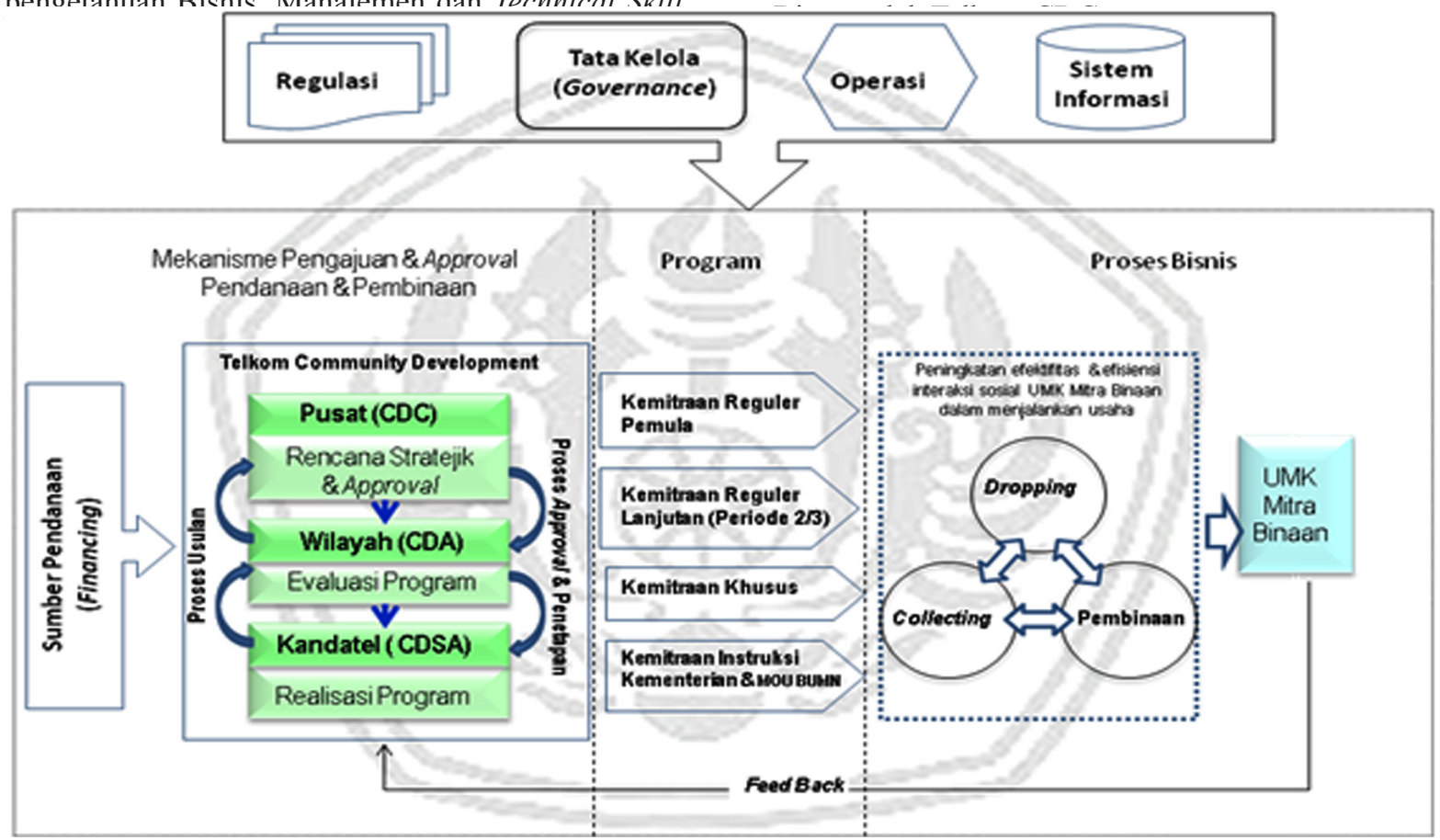

Sumber: Diolah Peneliti

Gambar 7 : Model Pemberdayaan Kelembagaan UMK Mitra Binaan Oleh Telkom CDC

\footnotetext{
35 Observasi lapangan dan wawancara dengan Officer Telkom CDSA Tasikmalaya, Garut dan Bandung.

36 Observasi lapangan dan wawancara dengan Senior Manajer Program Kemitraan Telkom $\mathrm{CDC}$

37 Osi lapangan dan wservWawancara dengan Officer Telkom CDSA Tasikmalaya, Garut, dan Bandung

38 KD.21/PR000/COP-B0030000/2010 tanggal 19 April 2010 tentang Pengelolaan Program Kemitraan dan Program Bina Lingkungan.

39 Ibid
}

2) Menggambarkan hubungan-hubungan yang signifikan antar unsur atau elemen yang memiliki signifikansi dalam pelaksanaan proses pemberdayaan kelembagaan UMK Mitra Binaan oleh Telkom CDC, 40 Quade, 2010: 141 
secara eksplisit, 3) Merumuskan hipotesis tentang sifat-sifat dari setiap hubungan, dan 4) Hipotesis dan atau prediksi model diuji dengan menggunakan data-data yang berhasil digali dan diperoleh pada saat penelitian di lapangan melalui tahapan tersebut, pemodelan proses pemberdayaan kelembagaan UMK Mitra Binaan oleh Telkom CDC yang berhasil dibangun peneliti adalah seperti digambarkan pada Gambar 7.

\section{Hasil Pengukuran Terhadap UMK Mitra Binaan Telkom CDC}

Daripengujian terhadap UMK sukses yang menjadi Mitra Binaan Telkom CDC menunjukkan bahwa proses pemberdayaan yang dilakukan Telkom CDC memiliki derajat yang baik, hal ini ditunjukkan dengan hasil penelitian yang menggambarkan terpenuhinya tiga syarat keberhasilan pem-berdayaan. ${ }^{41}$ yaitu: 1) Seluruh informan merasa memiliki kesempatan dan kemampuan untuk menentukan dan mendapatkan pilihan sesuai kebutuhannya, baik untuk kepentingan kehidupan pribadi maupun kelembagaan usahanya, ${ }^{42}$ 2) Seluruh informan merasa memiliki kemampuan dan kesempatan untuk menggunakan dan memanfaatkan pilihan yang berarti bagi kehidupan informan (the capacity to make meaningful choice), baik kehidupan pribadi maupun kehidupan kelembagaan usahanya, ${ }^{43}$ dan 3) Seluruh informan merasakan bahwa pilihan yang mereka miliki dan mereka manfaatkan, secara umum menghasilkan pencapaian (achievement) sesuai dengan yang mereka harapkan. ${ }^{44}$

\section{SIMPULAN}

Kesuksesan Pemberdayaan Kelembagaan UMK oleh Telkom CDC, didasari oleh adanya komitmen manajemen perusahaan dalam merealisasikan Program Kemitraan secara komprehensif dan konsisten, yang dilakukan melalui tata kelola yang baik (good governance), sebagaimana diuraikan pada hasil penelitian dan dimodelkan peneliti pada bagian pembahasan penelitian ini.

Pemberdayaan Kelembagaan UMK Mitra Binaan yang dilakukan oleh Telkom CDC adalah pemberdayaan untuk UMK yang belum memiliki kemampuan kelembagaan. Langkah ini menjadi solusi penting dan tepat untuk mengatasi kendala umum yang di alami dalam upaya pemberdayaan UMK di Indonesia, yaitu kesulitan untuk mendapatkan dana bantuan modal dari lembaga perbankan karena kelembagaan UMK yang belum "bankable".

Niat baik dan tujuan PT. Telkom yang direalisasikan dengan pemberdayaan kelembagaan UMK Mitra Binaan yang belum "bankable" menjadi lembaga usaha yang "bankable", hendaknya dapat tersosialisasikan dengan lebih baik. Informan sukses yang pada saat penelitian masih membutuhkan modal untuk berkembang, ternyata masih selalu berharap untuk mendapat bantuan

\footnotetext{
41 Alsop; Bertelsen; Holand, 2006: 15

42 Obserasi lapangan dan vwawancara terhadap Sembilan pelaku UMK Mitra Binaan Telkom CDC, yaitu tiga UMK di CDSA Tasikmalaya, tiga UMK di Garut, dan tiga UMK di Bandung

Obserasi lapangan dan vwawancara terhadap Sembilan pelaku UMK Mitra Binaan Telkom 43 Obserasi lapangan dan vwawancara terhadap Sembilan pelaku UMK Mitra Binaan Telkon $44 \mathrm{Ibid}$
}

Telkom CDC karena merasa nyaman, walaupun mereka sudah menyelesaikan tiga periode pemberdayaan dan sudah cukup mandiri. Kondisi ini dapat mengurangi kualitas dari tujuan pemberdayaan,

Khusus untuk pemberdayaan periode ketiga (terakhir) hendaknya Telkom CDC lebih mengarahkan penguatan kelembagaan UMK Mitra Binaan untuk disiapkan menjadi UMK yang "bankable" dan diarahkan menjadi nasabah perbankan,

Implementasi kebijakan "tiga periode masa pemberdayaan" yang ditetapkan perusahaan, sebaiknya tidak diterapkan secara "equal treatment" kepada seluruh UMK Mitra Binaan. Meskipun menunjukkan perkembangan, usaha berskala Mikro yang umumnya 'start-up business', memerlukan treatment yang berbeda dari usaha berskala Kecil. Dari wawancara terhadap informan usaha Mikro, mereka lebih membutuhkan pembekalan, arahan, pendampingan, dan pemagangan, sedangkan untuk usaha Kecil, lebih membutuhkan pengetahuan dan pemahaman untuk promosi/pemasaran dan atau pameran bagi produkproduk mereka.

Struktur organisasi Telkom CDC yang ditetapkan Direksi melalui KD.21/PR000/COP-B0030000/2010 tanggal 19 April 2010 tentang Pengelolaan Program Kemitraan dan Program Bina Lingkungan, sebaiknya dilengkapi sebagaimana yang terjadi di lapangan. KD.21/2010 hanya mengatur unit Telkom CDC (Pusat) dan unit Telkom CDSA (Wilayah/Area), sedangkan dalam realisasinya, penyelenggaraan Program Kemitraan ini melibatkan peran proaktif dari unit Telkom CDSA. Berdasarkan observasi peneliti, Telkom CDSA berperan penting mewakili perusahaan untuk berhadapan lang sung dengan UMK Mitra Binaan. Pada level Telkom CDSA ini, banyak hal penting terkait realisasi Program Kemitraan yang memerlukan konsentrasi, antara lain pendampingan, monitoring pembayaran angsuran, dan penanganan surat-surat berharga sebagai agunan pinjaman. Khusus penanganan agunan, perlu mendapat perhatian lebih serius, karena efek tanggung jawab petugas Telkom CDSA mewakili perusahaan, sangat besar.

\section{DAFTAR PUSTAKA}

Alsop, Ruth, Nina Heinsohn, 2005. Measuring Empowerment in practice: Structuring Analysis and Framing indicators, World Bank Policy Research Working Paper 3510, 1818 H. Street, NW. Washongton DC, 20433 USA.

Alsop, Ruth; Mette Bertelsen, Jeremy Holland. 2006. Empowerment in practice : from analysis to implementation, HN49.C6A375-2006, The International Bank for Reconstruction and Development/THE WORLD BANK, 1818 H Street, NW, Washington, DC 20433 USA.

Cornell Empowerment Group. 1989. Empowerment and family support. Networking Buletin, 1(1)2.

Creswell, John W. 2009 Research Design: Qualitatif, Quantitative, and Mixed Methods Approaches, Sage Publications, Inc. Thousand Oaks, CA 
Creswell, John W. 2010. Research Design, pendekatan Kualitatif, Kuantitatif, dan Mixed, terjemahan Fawaid, Ahmad, Pustaka Pelajar, Yogyakarta.

Development Committee, World Bank. 2002. World Development Report 2000/2001: Attacking Poverty, The International Bank for Reconstruction and Development, The World Bank, 1818 H. Street, NW, Washington, DC 20433 USA.

Lord, John and Hutchison, Peggy. 1993. The Process of Empowerment: Implications for Theory and Practic, Canadian Journal of Community Mental Health. 12:1, Spring 1993, pages 5-22.

North, Douglas C. 1990. Institutions, Institutional Change and Economic Performance. Cambridge: Cambridge University Press.

North, Douglas C. 1991. Institutions. The Journal of Economic Perspectives, Vol. 5, No. 1. Pp. 97-112. American Economic Association.

North, Douglas C. 1993. The New Institutional Economics and Development. Economic History Paper Serries 9309002, Econ WPA. Washington University, St. Louis. Missouri.

http://128.118.178.162/eps/eh/papers/9309/9309002.pdf.

Quade, E. S. 2010. Analysis for Public Decisions, Third Editions, Revised Edition by Grace M., Carter, A Rand Corporation Research Study, North-Holland, Amesterdam.

Sadan, Elisheva .2004. Empowerment and Community Planning. Tel. Aviv, Hakibbutz Hameuchad Publisher (in Hebrew).

Schmid, Alan, A. 2004. Conflict and CooperationInstitutional and Behavioral Economics. ISBN 1-4051-1355-3; 1-4051-1356-1. Blackwell,
Oxford, U.K.

Whiteside, Mary Elizabeth. 2009. A Grounded Theory of Empowerment in the Context of Indigenous Australia, James Cook University, http://eprints. jcu.edu.au/8228

Withmore, E. 1988. Participation, empowerment and welfare, Canadian Review of Social Policy, 22, 51-50

Zimmerman, Marc A. 1995. Psychological Empowerment: Issues and Illustrations, , American Journal of Community Psychology, Vol. 23, No.5. Plenum Publishing Corporation. USA.

KD.21/PR000/COP-B0030000/2010. 2010, Pengelolaan Program Kemitraan dan Program Bina Lingkungan.

Permeneg BUMN. 2007. Peraturan Menteri Negara BUMN No. PER-05/MBU/2007 tentang Program Kemitraan Badan Usaha Milik Negara Dengan Usaha Kecil dan Program Bina Lingkungan.

Telkom CDC. 2008. Analisis Kapabilitas Provinsi dan Kompetensi Usaha Kecil, Bandung, Indonesia.

Telkom CDC. 2009. Bersama Anda Menggenggam Dunia, Sustainability Report 2009, Bandung, Indonesia.

Telkom CDC. 2011. Direktori Usaha Kecil Mikro (UMK) Binaan Telkom, Bandung, Indonesia.

Undang-Undang. 2007. Undang-Undang Republik Indonesia No. 25 tahun 20007 tanggal 26 April 2007 tentang Penanaman Modal.

Undang-Undang. 2007. Undang-Undang Republik Indonesia No. 40 tahun 20007 tanggal 16 Agustus 2007 tentang Perseroan Terbatas.

Undang-Undang. 2008. Undang-Undang Republik Indonesia No. 20 tahun 20008 tanggal 4 Juli 2008 tentang Usaha Mokro, Kecil, dan Menengah. 